\title{
Na zakręcie \\ Krajobraz polskiej transformacji w filmach przełomu lat 80. i 90.
}

\author{
ILONA COPIK
}

Transformacja - w odniesieniu do przemian zapoczątkowanych w Polsce w 1989 r. obradami okrągłego stołu i pierwszymi po części wolnymi wyborami parlamentarnymi - może się wydawać określeniem zbyt ogólnikowym, biorąc pod uwagę zasięg zmian, jakie nastąpiły w sferze ekonomicznej i społeczno-kulturowej na przełomie lat 80. i 90. W rzeczywistości, jak wynika z ustaleń socjologów, transformacja jest ,,całościowym " zjawiskiem społecznym ${ }^{1}$, w którym polityczny fakt zmiany ustroju stanowi zaledwie wstęp do szerszych procesów, te zaś mają swoje fazy. Początkowo wydawało się, że chodzi po prostu o przejście - z niewoli totalitaryzmu do wolności opartej na zasadach liberalnej demokracji, z nieracjonalnej gospodarki nakazowo-rozdzielczej do dającej nieograniczone możliwości ekonomii wolnego rynku. Zmianie towarzyszyła euforia w sferze moralistycznej - oto nastąpił kres znienawidzonego reżimu, koniec epoki imperium zła ${ }^{2}$. Towarzyszyła temu wiara, że ład, który wcześniej zatriumfował na Zachodzie, sprawdzi się nad Wisłą. Szybko okazało się, że implementacja wzorców zachodnich i realizacja idei „powrotu do Europy” nie funkcjonuje jako uniwersalna norma, a świetlana kapitalistyczna przyszłość Polski to w dużej mierze myślenie życzeniowe. Kraj ogarnął chaos skrajności, z jednej strony wizja nieznanych dotąd luksusów, z drugiej - galopujące ceny, płynący z mediów przekaz o sile przedsiębiorczości jednostki i ludzka niemoc, nad którą wkrótce zawisło widmo utraty pracy. Okazało się, że rzeczywistość jest daleko bardziej pogmatwana, aniżeli z początku się wydawało, i że są różne rodzaje kapitalizmu. Miarą komplikacji była pogarszająca się sytuacja polityczna (tak zwana wojna na górze i podział „Solidarności” w 1990 r.), szybko też dały o sobie znać nowe konflikty i rozwarstwienia społeczne.

Jak wiadomo, kino polskie w okresie transformacji zostało dotknięte kryzysem w szczególny sposób. Pomijam tu znane kwestie instytucjonalne, problemy wynikające z ustania państwowego mecenatu, wejścia w orbitę procesów komercjalizacji, a także szeroko komentowany impas artystyczny, w jakim znalazły się filmy po zniesieniu cenzury. Opisywano tę sytuację w kategoriach elegijnych, pisząc o zniknięciu polskiego filmu ${ }^{3}$, czasie straconym ${ }^{4}$, a nawet śmierci polskiego kina ${ }^{5}$. Sami reżyserzy tłumaczyli ją odpływem widzów z kin, wszechobecną komercją i pirackim krążeniem filmów amerykańskich upowszechnianych na kasetach wideo, a także szybką dezaktualizacją tematów społecznych w zmieniającej się jak w kalejdoskopie polskiej rzeczywistości. Krytyka alarmowała z kolei, że polski film znika całkowicie z kin i ze świadomości potocznej ${ }^{6}$, stawiając bardziej konkretne tezy o pokoleniu zamilkłym ${ }^{7}$. Na łamach „Filmu” i „Kina” utyskiwano, że tak zwane pokolenie stanu wojennego ${ }^{8}$, którego odziedziczoną misją było stanąc 
twarza $w$ twarz z rzeczywistościa społeczna i polityczna ${ }^{9}$ i kontynuować dialog społeczny, nie spełniło pokładanych w nim nadziei. Nie spetniło oznaczało w tym wypadku, że nie utworzyło, wskutek generacyjnego rozproszenia, formacji porównywalnej do kina moralnego niepokoju i nie wypracowało nowych modeli pokazywania świata w sytuacji dezaktualizacji dawnej tematyki ${ }^{10}$.

Problem, o jakim mowa, naturalnie nie ogranicza się do kwestii rozbieżności między tym, co polski widz na początku lat 90. oglądał na ekranie, a czego mógł oczekiwać od kina. Skala kryzysu miała szerszy zasięg, zmiana systemowa zbiegła się bowiem w czasie ze zmianą cywilizacyjną, co powodowało nagłą konfrontację zarówno kina, jak i innych sztuk z procesami globalizacji i dehierarchizacji kultury. Przedmiotem mojego zainteresowania w tym szkicu nie jest jednak kontynuowanie refleksji historyczno-filmowych i/lub dokonywanie prób waloryzacji filmów powstałych w okresie przełomu 80./90. Interesuje mnie raczej filmowy krajobraz zmiany, zapisane w nim relacje fikcje/rzeczywistość i klimat przełomu. Chcę sobie zadać pytania: Jakim miejscem jest uwidoczniona na ekranie Polska tego okresu? Jaka jest jej specyfika lokalna? Jak filmy odzwierciedlają społeczeństwo i kulturę, a także jak kino tamtych lat rezonuje z przestrzenią zmieniających się wartości i światopoglądów? Dystansując się wobec definitywnych tez, że w okresie przełomu nie zdołano pokazać na ekranie przemian rzeczywistości i tożsamości spotecznej oraz skomplikowanej sytuacji bohatera ${ }^{11}$, chciałabym niejako na nowo przemyśleć, jak kino reprezentowało moment zmiany i jak uczestniczyło w produkcji nowej tożsamości. Mówiąc o krajobrazie „,na zakręcie”, mam przy tym na myśli pierwszą, najbardziej rewolucyjną fazę przełomu - lata 1989-1990, czas wdrażania tak zwanej Ustawy Wilczka ${ }^{12}$, pozwalającej na dokonanie cudu gospodarczego i czas przeprowadzania pierwszych częściowo wolnych wyborów, w trakcie których Polacy wybierali Sejm kontraktowy. Jest to okres wielkich nadziei i bezgranicznego zwątpienia, moment zmiany wszelkiego rodzaju nazw, czas afer gospodarczych wykorzystujących nisze systemowe niedojrzałego prawodawstwa, a także era prawdziwie nieskrępowanego piractwa medialnego.

\section{Wolność burzy mury}

Od filmów, które premierę miały w 1989 r., oczekiwano przede wszystkim, że będą wypowiedzią na miarę pokolenia i w autorski sposób skomentują dokonującą się rewolucję. Wśród dzieł cieszących się największym zainteresowaniem na festiwalu w Gdyni znalazły się więc utwory w różny sposób odnoszące się do tematu politycznej niewoli i determinacji ludzi w dążeniu do wolności. 300 mil do nieba (reż. Maciej Dejczer, 1989), oparta na faktach historia braci Kwiatkowskich, którzy pod podwoziem ciężarówki przedostali się do Danii, wywarł szczególne wrażenie, mimo że jego tematyka, nawiązująca do problemów rodem z poprzedniej epoki, w kontekście bieżących wydarzeń politycznych wydawać się mogła nieco spóźniona. Film ten niezwykle sugestywnie ukazywał jednak problem wolności jako uniwersalnej, fundamentalnej wartości, koncentrując się przy tym na emocjach, jakie rozpalały wyobraźnię widzów w zakresie realnego i wyimaginowanego kontrastu między Wschodem i Zachodem. Nie chodziło wyłącznie o to, że Polska jest krajem brudnym, szarym, nieefektownym ${ }^{13}$, kapitalizm zaś jarzy się bogactwem sklepowych wystaw ${ }^{14}$. Ukazana na ekranie emigracja dwóch małoletnich braci, de- 


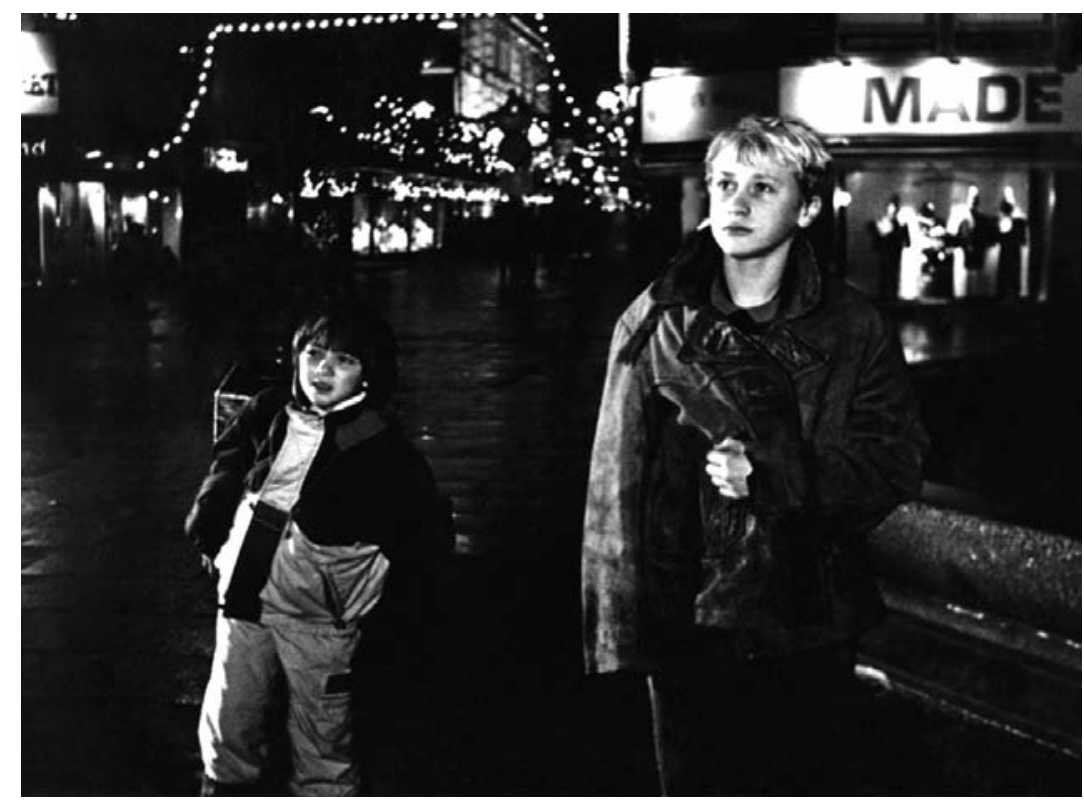

300 mil do nieba, reż. Maciej Dejczer (1989)

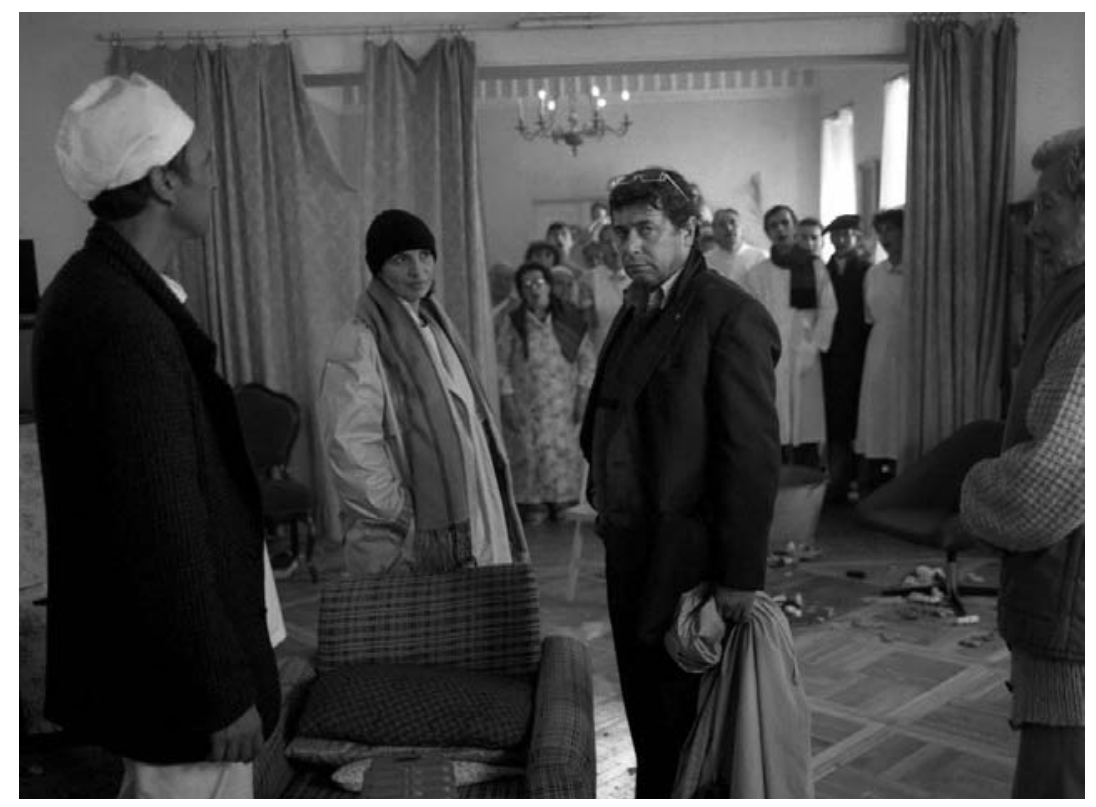

Ucieczka z kina Wolność, reż. Wojciech Marczewski (1990) 
cydujących się na porzucenie rodzinnego domu, jest ucieczką „do” kapitalizmu, który dla głównych bohaterów stanowi wizję mglistą, utkaną bardziej z marzeń aniżeli z konkretnej wiedzy. Decyzja chłopców nie wynika więc z młodzieńczego buntu czy świadomej kontestacji PRL-owskiej rzeczywistości, lecz z głębokiej wiary w istnienie lepszego świata, wolnego od obłudy, ucisku i nędzy, w którym będa mogli w końcu bez skrępowania rozwinać skrzydła ${ }^{15}$. I chociaż upragniony Zachód zasadniczo okazuje się niedoskonały (obraz filmowy podkreśla wyobcowanie $i$ samotność małych emigrantów $\left.{ }^{16}\right)$, to jednak ich decyzja szukania azylu nie traci na aktualności. Dorastali bowiem w przeświadczeniu o braku jakichkolwiek perspektyw we własnym kraju, widząc przykład ojca, którego ciężka praca nie jest w stanie zapewnić rodzinie godziwego bytu. Co istotne, młodzi bohaterowie 300 mil do nieba nie mają dylematów właściwych polskiej „tragedii emigracyjnej”, dostrzegalnych na przykład w filmie Ostatni prom (reż. Waldemar Krzystek, 1989), w którym pasażerowie płynący do Hamburga wciąż od nowa zadają sobie pytanie: „zostać czy wyjechać?”. Jak pisał Tadeusz Sobolewski: Dziecięcy, zdroworozsądkowy punkt widzenia pozwala ostentacyjnie odrzucić narodowe czy państwowe sentymenty. Nie da się żyć tutaj? Trzeba szukać miejsca gdzie indziej ${ }^{17}$. Ojcowskie pożegnalne słowa: Nigdy tu nie wracajcie, wyraźnie sugerują wyczerpanie się idei pedagogiki ojczyźnianej i dewaluację romantycznych wzorców, świadczą też o przekonaniu, że teraz liczy się instynkt samozachowawczy, który każe ratować siebie i najbliższych, nie zaś pokładać nadzieję w przebrzmiałych sentencjach. Warto dodać, że pragmatyzm bohaterów nie jest skierowany na osiągnięcie indywidualistycznego celu, ale łączy się z odpowiedzialnością za los bliskich. Bracia Kwiatkowscy, podobnie zresztą jak ich koleżanka Elka, zachowują się jak dorośli. Co więcej, to, co robia, jest popisem przedsiębiorczości, w przeciwieństwie do nich (...) dorośli ukazani sa jako niemrawi, zrezygnowani, pozbawieni inicjatywy ${ }^{18}$. Obraz dzieciństwa w filmie Dejczera jest nie tylko, jak to określił Mirosław Przylipiak: krzywym zwierciadtem dorostej rzeczywistości ${ }^{19}$, ale też stanowi sygnał, że młode pokolenie ma cechy, które pozwolą mu lepiej wykorzystać czas nadchodzącej zmiany.

Innym filmem, który jasno dawał do zrozumienia, że wychodzenie z systemu jest przede wszystkim sprawą młodych, był Ostatni dzwonek Magdaleny Łazarkiewicz (1989). Film powstawał jako autokomentarz do rzeczywistości. Jak mówiła reżyserka, realizując go, chciała uchwycić tamten czas ${ }^{20}$ i poczucie, kiedy coś wisiało w powietrzu, nabrzmiewało, wiedzieliśmy, że nie ma już odwrotu. Nie było tylko wiadomo, w która stronę wszystko się potoczy ${ }^{21}$. Młodość w jej ujęciu to nie tyle okres w życiu, ile zestaw cech szczególnie istotnych w czasie przełomu. Tworzy go wierność ideałom i bezkompromisowość, wiara w niepodważalne wartości i przejrzystość różnicy między dobrem i złem. Siedemnastolatka - pisała Bożena Janicka - bardziej obchodzi (...), jaki świat być powinien, niż jaki jest ${ }^{22}$. Nic dziwnego, że Ostatni dzwonek stał się dziełem kultowym dla generacji u progu transformacji wchodzącej w dorosłe życie. Odzwierciedlał bowiem wspólne doznania - zwyczajne szkolne stresy i zgrywy oraz bardziej doniosłe lęki i nadzieje, będąc przypowieścia o inicjacji do wolności, o przełamywaniu ograniczeńn ${ }^{23}$, opowiadając o narastaniu buntu, o rozwoju samoświadomości prowadzacym do rewolty, zmiany, wypowiedzenia się poprzez twórcza anarchię ${ }^{24}$. Był filmem o dojrzewaniu do polityki, do uczestnictwa w życiu społecznym, z nadzieją, że to uczestnictwo będzie 
pełne. Z drugiej strony był też manifestem idei „,pomarańczowej Alternatywy” stawiającym sobie za cel poprawianie oficjalnej wykładni historii i korygowanie postaw społecznych. Ukazanej na ekranie aktywności artystycznej młodzieży towarzyszyło idealistyczne przekonanie, że rewolucja jest dziełem oddolnym, w którym można (trzeba) wziąć udział. Nie było tu cienia podejrzenia, że zmiany dokonywaty się odgórnie. Nie byly inspirowane przez ruch społeczny ani negocjowane $z$ nim $^{25}$.

Szkoła jest w filmie Łazarkiewicz nie tylko przestrzenią dorastania, ale także, - na co wskazywał Tadeusz Lubelski - Polską w miniaturze, jak niegdyś w kinie moralnego niepokoju ${ }^{26}$. Tym samym szkolny terror można uznać za formułę odtwarzającą metodykę niewolenia obywateli stosowaną w PRL. Ów model społeczeństwa zbudowany z realiów szkoły działa jakby na dwie strony: demonstruje mechanizmy życia społecznego, postugując się szkoła, natomiast szkołę objaśnia mechanizmami życia społecznego ${ }^{27}$ - pisała Bożena Janicka. Przede wszystkim obowiązuje w nim ścisły podział społeczności szkolnej na: „oni” - dyrekcja szkoły, grono pedagogiczne, aparat ucisku, władza, SB i „my” - robotnicy, inteligencja, „Piwnica pod Baranami”, Jacek Kaczmarski i młodzież, której liderem jest Krzysztof Buk - współczesne wcielenie Bernarda Zygiera z Syzyfowych prac Stefana Żeromskiego ${ }^{28}$. Analogia z kanoniczną lekturą sięga zresztą głębiej, stanowiąc czytelny znak tego, że jeszcze raz nie udało się szkole wychować młodego pokolenia na filistrów, jeszcze raz nie udało się wychować w takim duchu, w jakim się chciało-Polaków ${ }^{29}$. Symbolem wolności staje się wyjście poza szkolne mury (działka, gdzie można napić się wina; scena teatralna, gdzie można być performerem), które jednak nie oznacza ucieczki z lekcji, a jedynie zorganizowanie zajęć gdzie indziej aniżeli w szkolnej sali, co daje możliwości porzucenia marszruty i wymknięcia się władzy dyrektora. W końcówce filmu pojawia się wątek znany z Ostatniego promu i 300 mil do nieba - chodzi mianowicie o oddemonizowanie naszego losu ${ }^{30}$. Wersy z wiersza Adama Asnyka śpiewane na tle napisów końcowych Ostatniego dzwonka: Przestańmy ciagle karmić się boleścią ${ }^{31}$ wskazują na nieadekwatność dawnej martyrologii. Zarazem uświadamiają widzowi, że oto otwiera się nowy czas, wraz z którym nabiera wagi pytanie: Co zrobić z odzyskana wolnościa? ${ }^{32}$

O tym, że tego rodzaju pytanie nie jest odosobnione, przekonuje jeden z najwybitniejszych filmów okresu przełomu, pełen aluzji i intertekstualnych powiązań - Ucieczka z kina Wolność Wojciecha Marczewskiego (1990). Film uznano za rozrachunkowy, za metaforyczna przypowieść o transformacji ustrojowej ${ }^{33}$. Transformacji, warto dodać, która nie dokonuje się w toku manifestacji czy politycznych negocjacji, lecz jest wynikiem wyczerpania się mechanizmów dotychczasowego systemu, a jego symbolem staje się bunt materii. Na ekranie ukazuje się polskie miasto (Łódź) u schyłku PRL - smutne ulice, zimne światło latarń, pospolitość i szarzyzna. Wciąż funkcjonuje Główny Urząd Kontroli Publikacji i Widowisk, działa cenzura, trwają urzędnicze zakulisowe rozgrywki. Na murach i ścianach gdzieniegdzie widać ulotki „Solidarności”, jednak duch zmiany gdzieś się ulotnił. Panuje przeświadczenie, że uciekać - w tym kraju nie ma gdzie, poza tym wszystko jest otoczone milicją ${ }^{34}$. A jednak klimat nadchodzącego przesilenia coraz bardziej daje o sobie znać, tworzy go protest dziennikarzy, bezkarność dzieci hałasujących w kinie na nudnym filmie, absurdalny operowy śpiew urzędników. Jego kulminacją 
staje się surrealistyczna scena, w której aktorzy grający w filmie o znamiennym tytule Jutrzenka odmawiają współpracy i niczym postaci z Purpurowej róży z Kairu Woody'ego Allena - przerywają projekcję. Krytykują szablonowy język dialogów i odmawiają udziału w zbanalizowanej fabule. Co więcej, wkrótce także niedawny cenzor decyduje się na przekroczenie ram kinowego ekranu, przejście do ogarniętego ideą wolności świata fikcji i przyłączenie się do rewolty.

Bunt zaczyna się w kinie, w którym następuje inwazja fikcji, aż do zatarcia granic między fikcja a życiem ${ }^{35}$. Film zdaje się bowiem wyprzedzać współczesność, oferując widzom gotowy scenariusz możliwych przyszłych zdarzeń. Jak pisano w recenzjach: PRL-owska urzędnicza rzeczywistość ulega stopniowo transformacji, aż do kompletnego rozprzężenia. Postacie z filmów i książek zaczynaja przenikać do rzeczywistości ${ }^{36}$, co - jak można wywnioskować - jest oznaką rychłego wyzwolenia. Kwintesencją marzeń o wolności jest ucieczka bohaterów z kina i wyjście na szczyt budynku, gdzie niczym lunatycy krążą w scenerii czarnych dachów. W tym podniebnym spacerze można widzieć symboliczne przejście od zakłamanej socjalistycznej rzeczywistości do demokracji pełnej nadziei i wolności. Cenzor, który też tam jest, mówi: zawsze chciałem tu wyjść ${ }^{37}$. Chociaż sprawa nie jest taka prosta. Nastała polityczna wolność, która jednak nie przyniosła radości, tylko melancholię. Przedtem żyło się jak w więzieniu o łagodnym stosunkowo rezimie. Wolność wyobrażaliśmy sobie trochę tak jak więźniowie, wygladajacy na świat przez zakratowane okna. Wszystko, co na zewnatrz, wydaje im się piękne. Łudza się, że gdy tylko wyjda za bramę, uczynia ze swoim życiem wszystko, co zechca. Będą żyć petnia życia. Jednak okazuje się to niemożliwe ${ }^{38}$ - pisał Tadeusz Sobolewski. W dyskusji, jaka toczyła się wokół filmu, argumentowano, że po pierwsze z dnia na dzień trzeba teraz będzie odrzucić cierpiętnicze slogany i zacząć stawać się „normalnym” krajem. Po drugie - pozostaje problem moralny. W kinie Wolność śpiewa się Dies Irae, a dzień odzyskania wolności jest dniem sądu. Zakończenie filmu pozostawia wprawdzie kwestię odpowiedzialności za udział w komunizmie otwartą, ogólnie jednak czas wychodzenia z niewoli jest pełen niepokoju, więcej tu pytań aniżeli odpowiedzi.

\section{W przestrzeni zamętu}

Filmem, który chyba najlepiej oddaje roziskrzoną emocjami atmosferę czerwca 1989 r., a zarazem już swoim tytułem sugeruje ekstremalność przestrzeni, jest pełnometrażowy debiut fabularny znanej dokumentalistki Marii Zmarz-Koczanowicz Kraj świata (1993). Przedstawiony w tym dziele moment wyswobodzenia się z jarzma komunizmu daleki jest od euforii i utrzymany raczej w tonie gorzko-satyrycznym. Mamy wolność, demokrację, a mimo to wciąż tkwimy jakby w tym samym miejscu ${ }^{39}$ - mówiła reżyserka o ówczesnej sytuacji w Polsce. Zgodnie z jej słowami na ekranie ukazuje się świat w stanie zawieszenia, świat „pomiędzy” dwiema różnymi rzeczywistościami, który wykazuje właściwości przestrzeni progowej i ma wszystkie cechy bycia na zakręcie, w trakcie zmiany ${ }^{40}$. To, co stare, definitywnie straciło aktualność, a to, co nowe, zbyt słabo rysuje się na horyzoncie, by człowiek mógł zyskać choćby pobieżną orientację co do przyszłego biegu rzeczy. Razem ze zmianą kursu politycznego z dnia na dzień zmienia się topografia miasta: aleja Świerczewskiego staje się aleją „Solidarności”, z placu, który teraz 
jest placem Bankowym znika pomnik Feliksa Dzierżyńskiego. Zmiany są zresztą dużo szersze i postępują lawinowo: dopiero co odjechała delegacja, która złożyła wieńce pod pomnikiem, funkcjonariusze ZOMO patrolują ulice, przed sklepami wciąż ustawiają się gigantyczne kolejki, ale na murach już wiszą hasła wyborcze nowej władzy, już rozlega się głos agitatorów nowego systemu.

Fakty ukazane w filmie doskonale korespondują z informacjami, które stanowiły treść pierwszych Wiadomości nadawanych przez Telewizję Polską, programu który zastąpił tendencyjny Dziennik Telewizyjny. Wojciech Reszczyński głosił wówczas z powagą w Teleexpressie: Nowe idzie, stare zostaje i jak to pogodzić? ${ }^{41}$, roztaczając wizję kraju zagrożonego hiperinflacją, kompletnymi brakami zaopatrzenia (realna groźba ustania rynku paliw), chaotycznym demontażem systemu spółdzielczego i zbywaniem majątków PZPR i ZSMP. Perspektywa zastosowana w filmie Zmarz-Koczanowicz przypomina jednak raczej punkt widzenia zwykłego człowieka. Zastosowanie tej oddolnej optyki widzenia rzeczywistości potęguje efekt absurdu, bowiem dostrzegane na każdym kroku sprzeczności i pozory wywołują powszechną dezorientację. Jedni drepczą w zapętlonym korowodzie „łańcucha serc", inni czekają na cud ogarnięci przeczuciem, że żadna racjonalna argumentacja w tej sytuacji nie ma racji bytu. Oto bowiem wielu Polakom załamał się dotychczasowy sposób rozumienia świata, zaś w obliczu dekadencji przełomu zamiast poszukiwać logiki, należałoby raczej uruchomić podświadomość. Fragmenty Kraju świata dotyczące cudu na drzewie i kolejki do uzdrowiciela ewidentnie oddają stan realnych emocji społecznych tego czasu. Nieprzypadkowo ogromną popularnością cieszyły się wówczas zdalnie prowadzone seanse rosyjskiego niekonwencjonalnego psychoterapeuty Anatolija Kaszpirowskiego, do którego pomocy niejednokrotnie się odwoływano, usiłując poradzić sobie z wyzwaniami codzienności (Czy Pan wie, co się u nas dzieje na Dworcu Centralnym albo w dzielnicy Praga Pólnoc? Niech Pan nie ustaje w wysiłkach, ja bardzo proszę ${ }^{42}$ ).

Osobliwy moment w czasie, o jakim mowa, Olga Drenda nazywa „duchologią polską”, błyskotliwie opisując czasoprzestrzeń kryzysu jako erę widmowo nieuchwytną, kiedy to Polska pływała w jakiejś kosmicznej prazupie, nad która rzadko ktoś się pochyla, chyba że trzeba wyłowić z niej jakieś polityczne haki ${ }^{43}$. Podobnie w filmie Kraj świata krajobraz dokonującej się transformacji spowija niebieskawa mgła, błądzą w niej ludzie zahipnotyzowani hasłami sprawiedliwości społecznej, a wszystko odbywa się w ponurych okolicznościach krzywych chodników, dziur w ścianach, odpadających tynków, symbolizujących atmosferę schyłku i rozpadu. Prawdziwą miarą beznadziei jest jednak kryzys wspólnoty. Jak pisał Tadeusz Sobolewski, Kraj świata przedstawia moment wielkiej deziluzji ${ }^{44}$, filmowy obraz jest przedrzé́nianiem tego, co od czasu zaborów byto u nas najświętsze: tęsknota do jedności, do mistycznego zespolenia, wieczne oczekiwanie na cud, na wielki narodowy dreszcz ${ }^{45}$. Film pokazuje upadek autorytetów, w tym także erozję mitu „Solidarności”, po którym zostały jedynie patetyczne symbole. Społeczeństwo polskie jest (...) chore, jest w goraczce, jeszcze mamy trzydzieści dziewięć z kreskami ${ }^{46}$ określał ten stan Tadeusz Konwicki. Z kolei Stefan Morawski pisał: (...) Żyjemy w erze, która wypada nazwać aleksandryjska. To znaczy takiej, w której zostaty złamane osie wspótrzędnych, wyblakły dotychczasowe aksjomaty, pogmatwaty się kierunki działań ludzkości. W efekcie nie bardzo wiadomo, do czego zmierzamy ${ }^{47}$. Film Zmarz-Koczanowicz trafia celnie w ten właśnie martwy punkt, w którym na- 


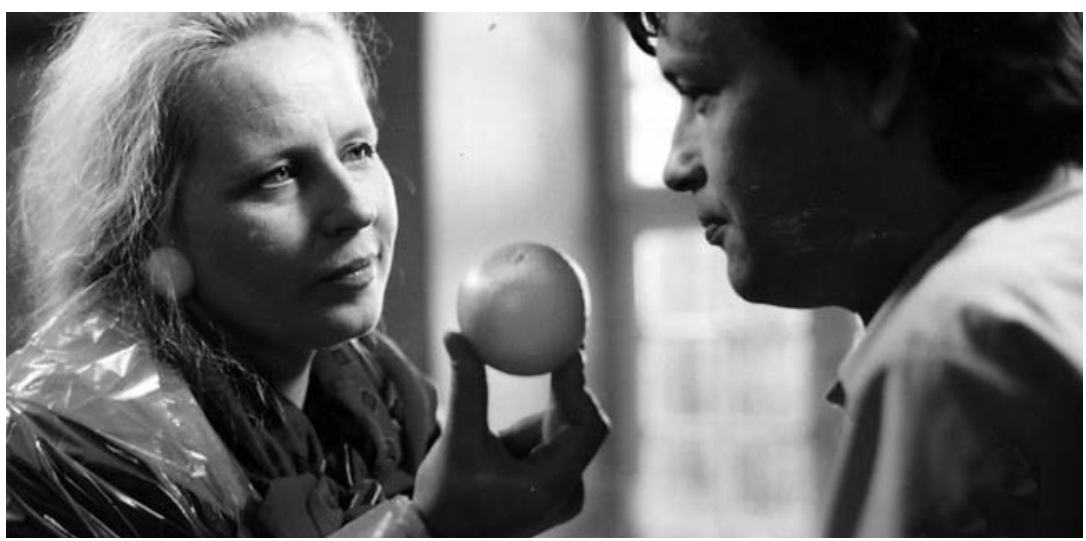

Zwolnieni z życia, reż. Waldemar Krzystek (1992)

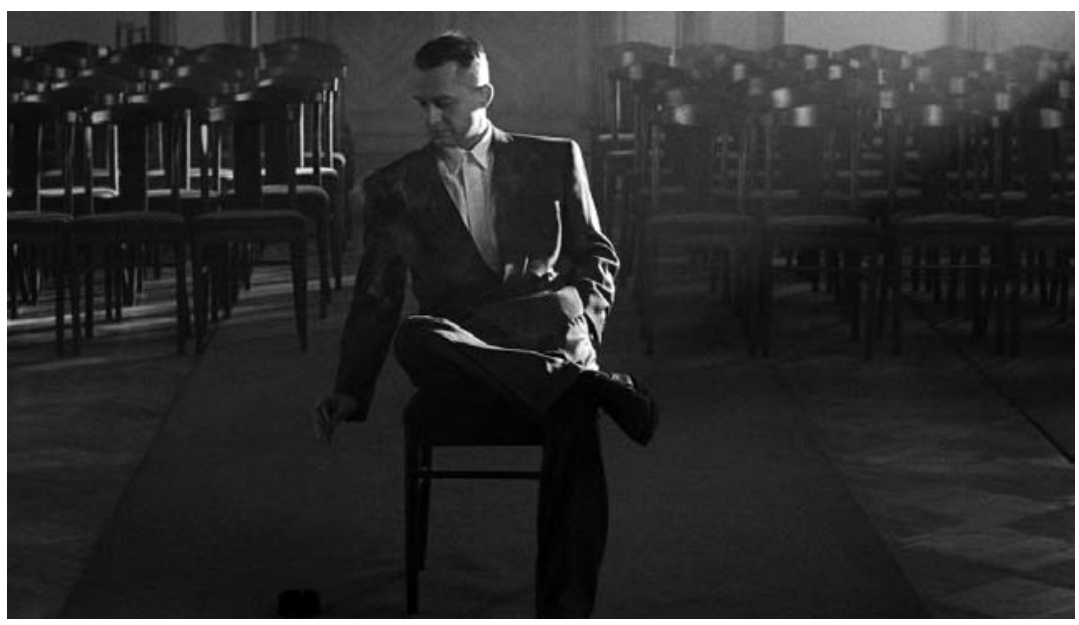

Psy, reż. Władysław Pasikowski (1992)

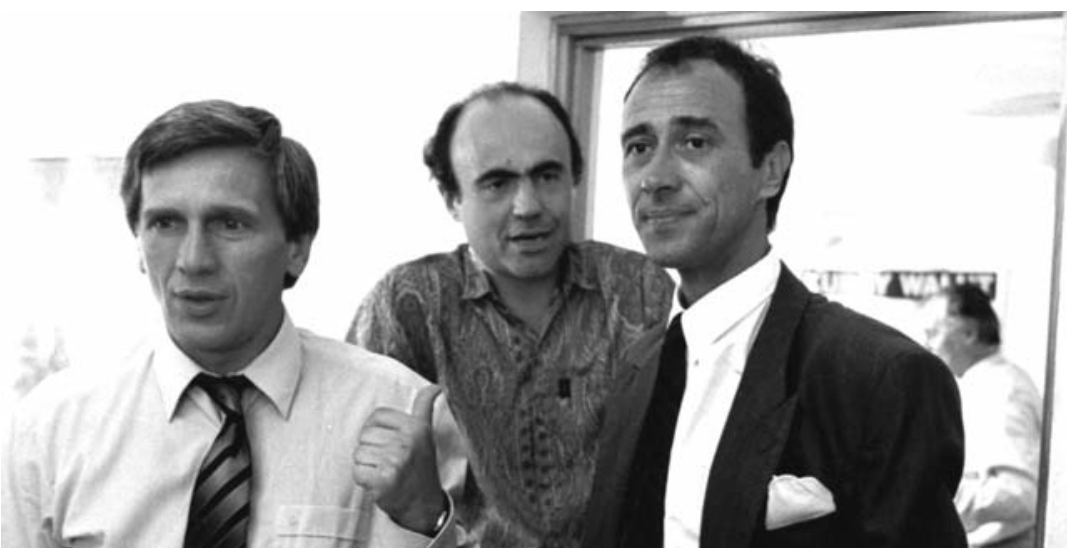

Wielka wsypa, reż. Jan Łomnicki (1992) 
sila się niewiedza i niewiara, traktuje się w nim z ironią to, co zostało z socjalizmu, ale nieufnością obdarza się również to, co nadchodzi.

Nieco inaczej moment przełomu ukazuje film Zwolnieni z życia (reż. Waldemar Krzystek, 1992). Co prawda i tutaj kamera skupiona jest na czasoprzestrzeni przełomu (Warszawa, grudzień 1989), a jej postrzeganiu także towarzyszy jakiś rodzaj zamętu (paranoja i amnezja głównych bohaterów). Nawiasem mówiąc, szaleństwo postaci $\mathrm{w}$ istotny sposób interferuje ze światem przedstawionym. Można odnieść wrażenie, że niejako wbrew temu, co pisał o filmie Jerzy Płażewski, całość przypomina momentami: sen wariata, śniony nieprzytomnie ${ }^{48}$. Gigantyczne śmietniska, prowizorka pierwszych hurtowni, labirynty bazaru, opuszczone budowy - niedokończone socjalistyczne projekty. Ta niewybredna sceneria, która odzwierciedla chaos przełomu i niedojrzałość nowej gospodarki, dość nieoczekiwanie staje się miejscem spotkania obłąkanej złodziejki - marzycielki tęskniącej za Paryżem z niewinnym młodzieńcem, na którego polują funkcjonariusze SB, obawiający się obciążających ich zeznań. Obecny w filmie wątek romansowy nie przesłania jednak zasadniczego, jak się wydaje, tematu Zwolnionych z życia, jakim jest problem transformacji, która wyrzuca niektórych ludzi na margines toczącego się przełomu. Media informują opinię publiczną o rozpoczynających się procesach, trwają polityczne oskarżenia, żywa jest pamięć o oprawcach. Tymczasem codzienność pokazuje, że wszystko jest albo za późno, albo bez sensu ${ }^{49}$ - jak określa to w filmie jedna z postaci. Czas zamykania rachunków jest czasem bezprawia, w którym bandyckie metody służą esbekom do ratowania własnej skóry. Dochodzenie sprawiedliwości przez zwykłego człowieka jest niemożliwe (Chcesz się mścić? Przecież nawet nie umiesz dać nikomu $w$ morde ${ }^{50}$ ). W tym kontekście słowa wypowiadane przez księdza w scenie mszy św. w kościele: I ci, którzy krzywdziliście, i ci, którzy byliście krzywdzeni, przekażcie sobie znak pokoju ${ }^{51}$, brzmią zbyt idealistycznie.

Niepodobna nie wspomnieć w tym miejscu o wątkach weryfikacji przeszłości SB obecnych w kinie popularnym tamtych czasów, mam na myśli zwłaszcza głośne Psy (reż. Władysław Pasikowski, 1992). Choć krytyka w większości nie zostawiła na filmie suchej nitki, zarzucając reżyserowi brak wartości artystycznych, epatowanie okrucieństwem i schematyzm (pisano m.in., że pokazuje zgniliznę moralna $i$ świat brudu, polskie realia $z$ tendencja do ich amerykanizowania ${ }^{52}$ ), film cieszył się niezwykłą popularnością widzów, przekraczając w 1993 r. liczbę 300 tys. Poza tym, że dzieło to stanowiło jawną kpinę z etosu „Solidarności” (słynna, uznana za świętokradczą scena, w której pijani ubecy niosą kolegę, wykrzykując kultową piosenkę opozycji Janek Wiśniewski padt) i było świadectwem duchowego ubóstwa ${ }^{53}$ zdeprawowanych funkcjonariuszy (określanych jako: głośna, agresywna i mizoginiczna banda ${ }^{54}$ ), nie można było przeoczyć faktu, że zawierała się w nim jednak jakaś empiria. Zapewne była to prawda o narodzie, w którym w wyniku dlugotrwałej sztuczności postaw i nieszczerości deklaracji (...) pomieszały się relikwie i symbole, tożsamości i rodowody ${ }^{55}$, jak pisał Maciej Parowski, dodając, że Pasikowski pokazat Polske w momencie przemiany i totalnego zamętu ${ }^{56}$. Podobnie określiła to Ewa Mazierska, uznając film za skutek reakcji na niezadowolenie i niepokoje odczuwane przez Polaków po upadku komunizmu i wprowadzeniu ekonomii rynkowej. Jej zdaniem: teraźniejszość to (...) czas politycznego, społecznego i moralnego chaosu, w którym każdy musi odnaleźć dla siebie nowe miejsce i nowe wartości ${ }^{57}$. 
Okoliczności zamętu, o jakich mowa, w dużej mierze tworzą dawne podziały społeczne: władza - obywatele, funkcjonariusze - przedstawiciele opozycji, do których rzeczywistość dodaje nowe konflikty i nowe uwarstwienia. Inaczej aniżeli w filmie Waldemara Krzystka, w Psach sposobem na uniemożliwienie władzom zbierania dowodów przeciw SB nie jest polowanie na świadków, lecz palenie akt. Faktyczną jednak przyczyną chaosu są tu nie tyle akty niszczenia dowodów winy, ile fakt, że wśród kapitulujących esbeków są tacy, którzy omijając procedury, płynnie wchodzą w nowe (gangsterskie) układy. Skutkiem tego „swoi” i „obcy” stają się nieodróżnialni, zaś walka nowo powołanej policji z narkotykowym klanem oznacza w istocie walkę ze „swoimi”, dawnymi kolegami po fachu. Z kolei w tle filmu Zwolnieni $z \dot{z} y c i a$ widzimy wątek polaryzacji dokonującej się w szeregach „Solidarności”, nie wszyscy spośród działaczy dostali się na Wiejską. Są przegrani tego systemu - słabsi, ci którzy nie maja szans na wielki tup ${ }^{58}$. Emocje społeczne i klimat tamtego okresu, z którym rezonuje film, można podsumować słowami: Poczucie zamętu, zagrożenia, niepewności było wówczas powszechne. Wielu ludzi czuło także, że zostali zdradzeni. Miało być szybko lepiej, a nie było. Obiecany dobrobyt okazat się dostępny nielicznym, natomiast większość ludzi (w tym wielu najbardziej zastużonych dla zwycięstwa „Solidarności”, jak robotnicy z wielkich kombinatów przemystowych) stanęła wobliczu zupetnie nowych, nieznanych uprzednio zagrożen ${ }^{59}$.

\section{Zarysy nowej ekonomii}

Kontrast pomiędzy tym, co stare, a tym, co nowe, uwydatnia się na ekranie wówczas, gdy pozostający świeżo w pamięci krajobraz PRL zostaje w nagły sposób skonfrontowany ze zmianą ustrojową. Jest to strategia często stosowana w kinie popularnym w okresie przełomu. Na przykład w filmie Feliksa Falka Kapitał, czyli jak zrobić pieniądze w Polsce (1989) Warszawę z roku 1989 widzimy oczami socjologa powracającego do kraju po kilku latach spędzonych na Zachodzie (staż na uczelni w Stanach Zjednoczonych). Już pobieżne spojrzenie na polską rzeczywistość uświadamia bohaterowi, jak bardzo kraj się zmienił. Przed Pałacem Kultury dokonuje się demontaż (nieistniejącego w rzeczywistości) pomnika Karola Marksa. Na ulicach już widać pierwsze bilbordy firm branży informatycznej i RTV: „Atari”, „Sanyo”, „Fisher”, „Sony” - wizualne symptomy przemian społeczno-ekonomicznych. Wkrótce staną się one głównymi wyznacznikami nowego typu krajobrazu przez Łukasza Zarembę określonego jako polobraz ${ }^{60}$, wytworzonego nie tyle wskutek działania mechanizmów typowych dla samego kapitalizmu, ile będącego efektem podejmowania prób konkretyzowania w przestrzeni polskich miast wyobrażeń o istocie kapitalistycznej ekonomii. Demonstracyjną oznaką dokonującej się rewolucji są dźwięki nobliwej Międzynarodówki wraz z pomnikiem odchodzące w przeszłość, zastępowane tanecznym rytmem piosenki Sukces radośnie śpiewanej przez Andrzeja Zauchę. Zrób, graj, pchaj się w przód! to słowa-klucze do nowej rzeczywistości kształtowanej na wzór zachodni (amerykański), w której liczy się pieniądz i przedsiębiorczość, a do której akces, jak głoszą media, każdy, kto chce coś znaczyć, powinien zgłosić ,już dziś”. Ten ideologiczny przekaz zmienia dawne znaczenie słowa „kapitał”. Zawarty w nim przedmiot zaawansowanej krytyki staje się teraz symbolem pożądania, zaś całą retorykę walki klas zastępuje idea nieograniczonych korzyści płynących z ,wartości dodatkowej”. 
Film Feliksa Falka ukazuje Polskę okresu przemian „na gorąco”, w sytuacji, kiedy jeszcze nie wiadomo, co z nich wyniknie. Brak dystansu do świata przedstawionego stał się zresztą powodem krytyki. Między innymi zarzucano reżyserowi brak zrozumienia i właściwej oceny ukazanej na ekranie rzeczywistości oraz konstrukcję bohatera, który jako inteligent w biznesie jeszcze nie wie, w co się przepoczwarza ${ }^{61}$. Pisano, że Falk robi film, nie zważając, że sam jest w podobnej sytuacji jak jego bohater, robi coś, co robić umie gorzej, nie wykorzystując właściwie (...) swojego czasu ${ }^{62}$. Oglądany po latach Kapitat wydaje się jednak filmem niepozbawionym wiarygodności, jeśli chodzi o ukazywanie specyfiki społeczno-kulturowej transformacji w jej początkowej fazie. Specyfiki, warto dodać, widzianej z perspektywy, w której możliwy był raczej przegląd wątków, symboli, postaw życiowych aniżeli jakaś konstruktywna krytyka. Na ekranie urzeczywistniają się więc zarysy nowej ekonomii i nowych stosunków społecznych pokazane w konfrontacji z dawnymi typami mentalności i relacji. Od wyobrażeń o przynależności do elity intelektualnej (uniwersytet, doktorat, etat) ważniejsza staje się myśl o prawach własności i scenariusz zysku (inwestycja kapitału, własny biznes, nieograniczone korzyści materialne). Żarłoczna logika ideologii wolnorynkowej, jaką karmią obywateli media, wprost domaga się porzucenia anachronicznej „osobowości tradycyjnej" ${ }^{63}$ i poddania się regułom ekonomicznej wydajności w nowym stylu. W przestrzeni miasta jak grzyby po deszczu wyrastają więc budki, blaszaki, rozkładane stoiska, będące wyrazem spełniania marzeń Polaków o kapitalizmie, które z jednej strony są oznaką specyfiki tego etapu przekształceń (rozwój drobnej przedsiębiorczości), z drugiej - niestabilności nowego porządku gospodarczego. Zasadniczą cechą tej przestrzeni jest jej zmienność. Bohater filmu Falka zaczyna od budki z frytkami, przerzuca się na usługi ksero, wchodzi w spółkę prowadzącą biuro matrymonialne, by skończyć swą przygodę z biznesem na produkcji żab. Inni także swobodnie zmieniają branże, nie zważając na to, że nie mają kwalifikacji do prowadzenia takiej czy innej firmy. W erze raczkującego kapitalizmu, jak wynika z filmu, wszystko jednak jest możliwe, trzeba tylko wykazać się przedsiębiorczością.

Jakkolwiek tej ostatniej pozornie nie brak głównemu bohaterowi, a wchodząc w rolę biznesmena, jest zdecydowany zmienić dawne poglądy, zwyczaje, a nawet styl życia, to jednak ogólnie jego działalność gospodarcza skazana jest na porażkę. $\mathrm{Na}$ drodze do sukcesu stoi bowiem po pierwsze samo państwo, które nadmiernie rozbudowaną biurokracją i kontrolą skutecznie studzi zapał prywatnej inicjatywy ${ }^{64}$, po drugie przeszkody natury społeczno-kulturowej. Wśród nich za zasadniczą można uznać kwestię generacyjną. Syn jako przedstawiciel pokolenia, które postrzega świat przez pryzmat telewizji i komputerów, natychmiast uczy się, co znaczy słowo „dywidenda”, i mógłby dawać ojcu lekcje przedsiębiorczości (ten wątek do granic absurdu rozwijał Waldemar Szarek w Mów mi Rockefeller, 1990). Film Falka pokazuje, że młodzi ludzie wchodzą w nowy ustrój bezkolizyjnie, przedstawiciele pokolenia rodziców mają z tym już pewne problemy. Niektórym towarzyszy entuzjazm, inni mają wciąż silne przekonanie, że warto byłoby mieć plan rezerwowy na wypadek, gdyby na przykład jutro zmienit się ustrój ${ }^{65}$. Tym, co różni ludzi, jest zakres tolerancji na zmianę społeczną i stopień otwarcia mentalnego na skutki tej zmiany, a także wrażliwość moralna - nowy etos wolnorynkowy okazuje się zbiorem zasad nie dla każdego, podobnie jak nie dla wszystkich mottem życiowym może być maksyma „cel uświęca środki”. Pragnienie dołączenia za 
wszelką cenę do rozwiniętego Zachodu i wyrównania społecznych zapóźnień rozwojowych nie uwalnia od poczucia wstydu wobec niektórych praktyk komercyjnych, skazując często tożsamość na uwięzienie w kłopotliwej sytuacji „pomiędzy”.

Ponieważ ogniskiem uwagi w filmie Kapitat, czyli jak zrobić pieniądze w Polsce jest sfera ludzi interesu, nie ma tu „odrzuconych”, „wykluczonych”, wszystkich tych, którzy gorzej radzili sobie $w$ warunkach kapitalistycznej gospodarki ${ }^{66}$, jak to określił Tadeusz Lubelski. Są za to beneficjenci wolnego rynku, „młode wilczki” - warstwa nowobogackich, którzy mają być forpocztą nowej klasy średniej ${ }^{67}$. Ich cechą pozostaje wysoko waloryzowana zdolność do gromadzenia pieniędzy, a wyrazem pozycji społecznej - określone miejsca zamieszkania, takie chociażby jak osiedle szeregowych domków szumnie określane „Beverly Hills”. Zamieszkują je hurtownicy, przedstawiciele najbardziej chodliwych branż (tu butiki, gry komputerowe, studio wideo, tam szmaty i ręczniki ${ }^{68}$ ). Co istotne, punkt obserwacyjny reżyser Kapitału umieścił jednak poza tą grupą, wskutek czego widz odczuwa sceptycyzm co do zbyt dosłownie pojętej idei dorabiania się za wszelką cenę (w czym utwierdza go zresztą bankructwo głównego bohatera). Można by dodać, że bezkrytyczna fascynacja środowisk inteligenckich nowymi możliwościami ekonomicznymi, tak jak została ukazana na ekranie, stanowi znaczne uproszczenie. Jak wynika $\mathrm{z}$ analiz socjologicznych, inteligencja $\mathrm{w}$ okresie transformacji w większości zachowała swój etos i pozycję w hierarchii społecznej, co przeczy tezie, jakoby naukowcy z ochotą porzucali etaty uniwersyteckie i zakładali bary z frytkami. Istotną rolę odegrała tu międzypokoleniowa transmisja pozycji społecznej, a także wpływ czynników pochodzeniowych i wykształcenia, które w powszechnej opinii jednostek wciąż było najlepszą strategią akumulacji kapitału ${ }^{69}$.

Film Kapital, czyli jak zrobić pieniadze w Polsce ukazuje wolny rynek jako ten, który tworzy zupełnie nową sytuację społeczno-ekonomiczną W innych filmach z początku lat 90. przypomina się czasem, że kapitalizm jest ustrojem, który był już przecież polskim udziałem. Taki obraz kreuje Filip Bajon w Lepiej być piękna i bogata (1993), filmie opowiadającym o losach biznesmenki ratującej fabrykę włókienniczą przed upadłością spowodowaną polityką dumpingową, przełamując zarazem często pojawiający się na ekranie stereotyp, że to mężczyzna jest prawdziwym człowiekiem interesu. Socjalizm jako ustrój oparty na zasadach gospodarki centralnie zarządzanej odpowiada tu nie tylko za nieefektywność ekonomiczną, prowadzącą do upadku państwowych przedsiębiorstw, ale także za zrywanie ciągłości pokoleniowej i pamięci (fabryka była własnością dziadka głównej bohaterki przebywającego od czasów powojennych na emigracji), która dopiero po upadku systemu może zostać przywrócona. Z kolei w filmie Jana Łomnickiego Wielka wsypa (1992) wyrażony jest pogląd, że w 1989 r. nie wszystko się zmieniło. Tak zwani ludzie inteligentni w czasach kapitalizmu mają robić to, co robili dawniej, tylko oficjalnie i na dużą skalę ${ }^{70}$. Muszą jedynie wiedzieć kiedy i mieć informacje z pierwszej ręki ${ }^{71}$. Te możliwości zyskują za sprawą koneksji na najwyższych szczeblach władzy, które są pozostałością dawnych peerelowskich układów.

Warto się zatrzymać przy tym ostatnim filmie, ponieważ nawiązuje on w pewien sposób do wydarzeń, które faktycznie miały miejsce w przestrzeni społecznej. Pierwszy etap transformacji przedstawiony jest tu jako „złote czasy” dla wszystkich tych, którzy potrafili wyczuć moment zmiany - na przykład wykorzystać szalejącą hiperinflację i pod przykrywką kantoru, a jeszcze lepiej parabanku, wymieniać na 
szeroką skalę złotówki na dewizy. Pomysł Wielkiej wsypy opiera się na wykorzystaniu stereotypu Polaka - kombinatora i lichwiarza, który doświadczenie w zakresie handlu obcą walutą zdobył w czasach stanu wojennego, uwikłany w afery gospodarcze cudem umykał organom ścigania, w wolnym kraju zaś szybko stał się rekinem finansjery. Przygody pana Jareczka, sprytnie robiącego użytek z tradycyjnie brzmiącego nazwiska i zakładającego „Kasę Branickiego”, której ufają tysiące Polaków, powierzając swoje oszczędności, do złudzenia przypominają działalność Lecha Grobelnego, niechlubnego założyciela Bezpiecznej Kasy Oszczędności. Podobnie jak bohater filmu, prezes Grobelny najpierw wykorzystał społeczne zapotrzebowanie na cud (obiecując procent kilkakrotnie wyższy aniżeli PKO), zebrał od ludzi pieniądze, a w niespełna rok od założenia firmy zniknął z całą gotówką ${ }^{72}$. Jego przypadek z jednej strony uzmysławia mechanizm powstawania tak zwanej piramidy finansowej, z drugiej stanowi przykład powiązania sfer biznesu z dawnymi Służbami Bezpieczeństwa, w których szeregach nie wszyscy funkcjonariusze zostali zweryfikowani. Ponadto w filmie Łomnickiego zmiana nadweręża mit „Solidarności” sugestią, że wśród opozycjonistów byli także blagierzy, którzy pod pozorem walki z komuną faktycznie realizowali prywatne interesy. Pojawiają się tu także wątki niewiary w szczerość intencji polityków. Podobnie jak w innych dziełach zaliczanych do tak zwanego nurtu bandyckiego, do którego Wielka wsypa mogłaby być przygrywką, takich jak: Kroll (reż. Władysław Pasikowski, 1991), Uprowadzenie Agaty (reż. Marek Piwowski, 1993) czy wspomniane już $P s y$, przesłaniem jest przekonanie, że zamożność musi być skutkiem uprawiania jakiegoś przestępczego procederu, a wszystkie instytucje są skorumpowane, obsadzone przez sprzedajnych polityków i urzędników, często zreszta wywodzacych się wprost z poprzedniego systemu ${ }^{73}$.

Film Wielka wsypa, podobnie jak wcześniej analizowany Kapitał, czyli jak zrobić pieniądze w Polsce, pokazywał, że przełom uruchomił w przestrzeni publicznej nowe, nieznane dotąd strefy, będące wyrazem tyleż ekspansji nowej ekonomii, ile objawem początków społecznego istnienia warunkowanego przez konsumpcję. Ich znakiem były wyrastające $\mathrm{w}$ centrum Warszawy przeszklone wieżowce, przestronne biura $\mathrm{z}$ białymi ścianami i meblami, obrotowymi krzesłami, faksami i komputerami. W charakterze dodatków krążyły w przestrzeni uwolnione od cenzury teksty i obrazy udostępniane na witrynach i reklamach sex shopów i agencji towarzyskich oraz puszczane w obieg na kasetach wideo. Symbolem wizerunku biznesmena z wyższych sfer stała się biała marynarka, ciemne okulary i - co jak można przypuszczać, wynikało z prób naśladowania hollywoodzkich gwiazd włosy przyczesane na żel ${ }^{74}$, taki image przyjął główny bohater filmu Łomnickiego. Towarzyszące mu kobiety z kolei to najczęściej sekretarki w nastroszonych fryzurach, krótkich spódniczkach, z błyszczącymi torebkami u boku. Rzecz jasna, luksusowe samochody, eleganckie kobiety, mężczyźni $w$ świetnie skrojonych garniturach, wszystko to fotografowane $w$ manierze przypominajacej wysmakowane zdjęcia reklamowe, byto w istocie fotografia stanu marzeń, a po części także rejestracja zamętu mentalnego, jaki czyniła propaganda bogactwa w kraju ubóstwa ${ }^{75}$. W rzeczywistości naród w okresie zmiany z nagła i niespodziewanie konfrontowany był $\mathrm{z}$ symptomami podziałów ekonomicznych typowych dla gospodarki kapitalistycznej, będących wyrazem skrajnych możliwości, jakie daje wolny rynek. Ich znakiem z jednej strony były pięciogwiazdkowe wnętrza hotelu „Marriott”, z drugiej - bazar pod Pałacem Kultury. O tym, że nie wszyscy dali się 
uwieść ideologii sukcesu, świadczą ukazane w niektórych filmach postawy zwątpienia. Warto w tym miejscu wspomnieć chociażby komedię Barbary Sass Pajęczarki (1993), w której bohaterki - młode wykształcone dziewczyny, nie widząc dla siebie szans w kraju, decydują się na emigrację do Stanów Zjednoczonych, czy też film Łukasza Wylężałka Balanga (1993). W tym ostatnim Polskę określono bardziej dosadnie jako „zasrany kraj” pełen szarych bloków i krzywych chodników, otoczony aurą nieustającej napowietrznej libacji, kraj, z którego najlepiej byłoby uciec.

\section{Wnioski}

Można by podsumować, że filmy z przełomu lat 80.i 90, jakkolwiek odnoszą się do problematyki transformacji ustrojowej w sposób wybiórczy, nie uwzględniając wielu wątków i tematów ${ }^{76}$, ukazują jednak dość wyraźnie krajobraz dokonującego się przełomu. Szczególnie jest to widoczne, gdy weźmie się pod uwagę moment liminalny, przez politologów nazywany tranzycją, czyli jedna z pierwszych i stosunkowo krótkotrwała fazę przemian, obejmująca podejmowanie decyzji o zmianie systemu $i$ tworzenie ogólnych ram funkcjonowania nowego systemu ${ }^{77}$. Uwiecznioną w filmach cechą tej czasoprzestrzeni jest z jednej strony przesilenie, które wskazuje na wypalenie się ideologii, kryzys instytucji państwowych i determinację społeczeństwa (szkoła, z której wymykają się uczniowie; filmy, z których uciekają bohaterowie, ludzie, którzy wychodzą na ulicę), z drugiej - żywioł zmiany (burzenie pomników, zmiany nazw ulic i placów, reorganizacje urzędów). W wielu filmach daje o sobie znać koniec martyrologii narodowej, ale ujawnia się też erozja jednoczącego zbiorowość mitu „Solidarności” i pojawiają się pytania, co dalej począć z odzyskaną wolnością. Ogólnie jednak częściej aniżeli z destrukcją systemu politycznego i jej skutkami mamy do czynienia z reprezentacją nowych sfer wolnego rynku i związanych z tym przemian tożsamości. Dostrzegli to zresztą przed laty autorzy Kina najnowszego, którzy pisali: zdecydowana większość filmów o teraźniejszości zajmuje się przede wszystkim portretowaniem skutków nagłego pojawienia się w Polsce sfer bogactwa oraz zwiąanych z tym pokus materialnych ${ }^{78}$.

O ile jednak sam temat nowej ekonomii pojawia się na ekranie często (zazwyczaj w konwencji komediowej), o tyle sposób problematyzowania poszczególnych wątków i rozkład akcentów przedstawia się już rozmaicie. Transformacja gospodarki raz ukazywana jest jako nadejście zupełnie nowych czasów i możliwości, innym razem jako jakiegoś rodzaju kontinuum albo też powrót do przeszłości. Rzadko towarzyszy temu niezachwiana wiara w niewidzialną rękę rynku i doskonałość zasad liberalizmu ekonomicznego, częściej bardziej lub mniej stanowczo wyraża się sceptycyzm. Faktycznie stan emocji społecznych w omawianym okresie był daleki od euforii, cechowały go raczej dezorientacja i zakłopotanie. Pisze o tym obszernie Jadwiga Staniszkis: Postkomunistyczna transformacja w sposób paradoksalny łączy przekonanie, że uczestniczy się $w$ doniostym procesie historycznym - z trudnościa myślowego ulokowania $w$ czasie $i$ zidentyfikowania rodzacego się systemu ${ }^{79}$. Jest to zatem stan, w którym egzystencja jest skazana na kłopotliwą pograniczność, bycie pomiędzy jednym a drugim ustrojem, jedną i drugą rolą społeczną, starą i nową pracą, dawną (neotradycyjną) i nową (coraz bardziej płynną) tożsamością. Wrażenie „, bycia pomiędzy” jest spotęgowane przez hybrydowy charakter wytaniajacego się systemu i trwałość hierarchii z okresu komunizmu ${ }^{80}$. Nie 
wszystkie filmy wyrażają wspomniane animozje wprost, w niektórych pojawiają się one gdzieś w tle. Ogółem filmowy krajobraz pierwszego etapu transformacji wskazuje jednak na trudne wchodzenie społeczeństwa w nową rzeczywistość. Jeśliby się zgodzić z tezą, że kino nie przedstawiło satysfakcjonująco okresu przemian, to trzeba by dodać, że nie tyle może nie sprostało swoim czasom, ile raczej utknęło w kryzysie reprezentacji, pogrążyło się w niemożności znalezienia formuły pozwalającej wyrazić sens świata w tym krytycznym momencie. Być może wynika to z nadmiaru pytań i problemów nurtujących ówczesną rzeczywistość.

ILONA COPIK

${ }^{1} \mathrm{~J}$. Szacki, Nauki społeczne wobec wielkiej zmiany, w: Zmiana społeczna. Teorie $i$ doświadczenia polskie, red. J. Kurczewska, PAN, Warszawa 1999, s. 123.

2 Tamże, s. 127.

${ }^{3}$ Pokolenie, które zamilkło, ,Kino” 1991, nr 25, s. 3.

${ }^{4}$ Tamże.

${ }^{5}$ Tamże.

${ }^{6}$ Tamże.

${ }^{7}$ Tamże.

${ }^{8}$ Terminem Świadectwa metryk posłużył się Piotr Wasilewski w specjalnym wydawnictwie Biblioteki Powiększenia, zaliczając do tego grona reżyserów takich jak: Mirosław Bork, Maciej Dejczer, Robert Gliński, Waldemar Krzystek, Maria Zmarz-Koczanowicz, Magdalena Łazarkiewicz, Jan Kidawa-Błoński, Jerzy Morawski, Jacek Skalski. Zob.: T. Sobolewski, My sie jeszcze spotkamy, „Kino” 1991, nr 25, s. 4.

${ }^{9}$ A. Werner, Co dalej za tym zakrętem?, „Kino” 1990, nr 24, s. 7.

${ }^{10}$ Zob. M. Radkiewicz, ,,Młode wilki” polskiego kina. Kategoria gender a debiuty lat 90., Wydawnictwo Uniwersytetu Jagiellońskiego, Kraków 2006, s. 39-47.

${ }^{11}$ K. Gałuszka, Kocham ten kraj. O pewnym „młodym” polskim pokoleniu, „Kwartalnik Filmowy" 2003, nr 43, s. 205.

12 Ustawa o działalności gospodarczej z dn. 23.12.1988., http://prawo.sejm.gov.pl/isap.nsf/download.xsp/WDU19880410324/O/D19880324.pdf (dostęp: 16.03.2019).

${ }_{13}$ M. Przylipiak, Krzywe zwierciadto dorostej rzeczywistości, „Kino” 1990, nr 24, s. 15.

${ }^{14}$ Tamże.

${ }^{15}$ A. Przepiórska, Ucieczka do kapitalizmu ucieczka od kapitalizmu. Analiza porównawcza ,300 mil do nieba” M. Dejczera i ,Zmruż oczy” A. Jakimowskiego, w: Kino polskie po roku 1989, red. P. Zwierzchowski, D. Mazur,
Wydawnictwo Uniwersytetu Kazimierza Wielkiego, Bydgoszcz 2007, s. 142.

${ }^{16}$ M. Przylipiak, Krzywe zwierciadto dorostej rzeczywistości, dz. cyt., s. 15.

${ }^{17}$ T. Sobolewski, Nieuchwytne przeżycie, „Kino” 1989, nr 23, s. 9.

${ }^{18}$ Tamże.

${ }^{19}$ M. Przylipiak, dz. cyt.

${ }^{20}$ Co zrobić z wolnościa, M. Miodek rozmawia z M. Łazarkiewicz, „Film” 1990, nr 1, s. 7.

${ }^{21}$ Tamże.

22 B. Janicka, Późni wnukowie Bernarda Zygiera, „Kino” 1990, nr 24, s. 11.

${ }^{23}$ T. Sobolewski, Nieuchwytne przeżycie, dz. cyt., s. 8.

${ }^{24}$ Co zrobić z wolnością?, dz. cyt., s. 7.

${ }^{25}$ M. Gdula, 4 czerwca 1989. Jak naród nie obalit komuny, „Krytyka Polityczna” 04.06.2014. https://krytykapolityczna.pl/kultura//historia/4czerwca-1989-jak-narod-nie-obalil-komuny/2014/ (dostęp: 16.03.2019).

${ }^{26}$ T. Lubelski, Historia kina polskiego. Filmy, twórcy, konteksty, Videograf II, Katowice 2009, s. 497.

${ }^{27}$ B. Janicka, dz. cyt., s. 11-12.

${ }^{28}$ Tamże.

${ }^{29}$ Tamże, s. 12

${ }^{30}$ T. Sobolewski, Nieuchwytne przeżycie, dz.cyt, s. 8.

${ }^{31}$ Tamże.

${ }^{32}$ Co zrobić z wolnościa??, dz. cyt., nr 1, s. 6-7.

${ }^{33}$ T. Lubelski, dz. cyt., s. 518.

${ }^{34}$ Cytat z filmu Ucieczka z kina Wolność.

${ }^{35}$ T. Sobolewski, Cenzor-lunatyk, „Film” 1990, nr 15, s. 12.

${ }^{36}$ Tamże.

${ }^{37}$ Cytat z filmu Ucieczka z kina Wolność.

${ }^{38}$ T. Sobolewski, Czy Polska będzie zbawiona?, „Kino” 1990, nr 11-12, s. 3-5.

${ }^{39}$ Wolę się śmiać. Z Marią Zmarz-Koczanowicz rozmawia Tadeusz Sobolewski, „Kino” 1994, nr 28, s. 9. 
${ }^{40}$ A. Werner, dz. cyt., s. 7.

${ }^{41}$ Wiadomości z dn. 18.11.1989., https://www.youtube.com/watch? $\mathrm{v}=\mathrm{qJjn}$ Xqvkc60 (dostępność: 16.03.2019).

${ }^{42}$ Kaszpirowski potrzebny od zaraz „Film” 1990, nr 69, s. 6.

${ }^{43}$ O. Drenda, Duchologia polska. Rzeczy i ludzie w latach transformacji, Wydawnictwo Karakter, Warszawa 2016, s. 14.

${ }^{44}$ T. Sobolewski, Feliks Edmundowicz ze styropianu, „Kino” 1993, nr 307, s. 5.

${ }^{45}$ Tamże.

${ }^{46}$ Wróżby z dnia dzisiejszego. Z Tadeuszem Konwickim rozmawia Andrzej Werner, „Kino” 1991, nr 25, s. 4-5.

${ }^{47} \mathrm{~S}$. Morawski, Ani wolności, ani równości, ani braterstwa - a co w zamian?, ,Kwartalnik Filmowy" 1994, nr 5, s. 17.

${ }^{48}$ J. Płażewski, Ciekawe sytuacje, znaczace zachowania, „Kino” 1993, nr 305, s. 45.

${ }^{49}$ Cytat $\mathrm{z}$ filmu Zwolnieni z życia.

${ }^{50}$ Tamże.

${ }^{51}$ Tamże.

52 B. Janicka, Pies i karawana, „Film” 1993, nr 23, s. 3.

${ }^{53}$ M. Parowski, Podmienione relikwie?, „Film” 1993, nr 31-32, s. 39.

${ }^{54}$ E. Mazierska, Pogrążony $w$ kryzysie. Portret mężczyzny $w$ polskim kinie postkomunistycznym, „Kwartalnik Filmowy” 2003, nr 43, s. 189.

${ }^{55}$ M. Parowski, dz. cyt.

${ }^{56}$ Tamże.

${ }^{57}$ E. Mazierska, dz. cyt. s. 185.

${ }^{58}$ B. Janicka, Kto się nie boi w czarnym lesie, „Film” 1993, nr 1, s. 14.

${ }^{59}$ M. Przylipiak, J. Szyłak, Kino najnowsze, Wydawnictwo „Znak, Kraków 1999, s. 185-186.

${ }^{60}$ Ł. Zaremba, Bilbord, w: Kultura wizualna w Polsce, tom 2, Spojrzenia, red. I. Kurz, P. Kwiatkowska, M. Szcześniak, Ł. Zaremba, Fundacja „Bęc Zmiana”, Warszawa 2017, s. 15.

${ }^{61}$ B. Janicka, Ściskając $w$ ręku parę zielonych, „Film” 1990, nr 10, s. 7.
${ }^{62}$ A. Werner, dz. cyt., s. 6.

${ }^{63}$ M. Szcześniak, Ł. Zaremba, Sztandar, w: Kultura wizualna $w$ Polsce... dz. cyt., s. 139.

${ }^{64}$ Zob. K. Puto, Film jako ,, chtopiec z Marriotta". Ideologia kina polskiej transformacji (1987-2005), s. 45-50, https://www.academia.edu/28430290/Film_jako_ch\%C5\%82opiec_z_Marriotta_.Ideologia_kina pol skiej_transformacji_1987_2005__(dostęp: 16.03.2019).

${ }^{65}$ Cytat z filmu Kapital, czyli jak zrobić pieniadze $w$ Polsce.

${ }^{66}$ T. Lubelski, dz. cyt., s. 534.

${ }^{67}$ Szerzej zob. H. Domański, Nowe identyfikacje klasowe i nowe podziały społeczne, w: Zmiana społeczna, dz. cyt. s. 167.

${ }^{68}$ Cytat z filmu Kapital, czyli jak zrobić pieniadze $w$ Polsce.

${ }^{69}$ A. Giza-Poleszczuk, M. Marody, A. Rychard, Strategie Polaków wobec zmiany systemowej, w: Zmiana społeczna, dz. cyt. s. 212.

${ }^{70}$ Cytat z filmu Wielka wsypa.

${ }^{71}$ Tamże.

72 P. Pytlakowski, Nasza pierwsza piramida, „Polityka” 28.08.2012. https://www.polityka.pl/tygodnikpolityka/rynek/1529757,1,historia-polskich-piramid-finansowych.read (dostęp: 16.03.2019).

${ }^{73}$ M. Przylipiak, J. Szyłak, dz. cyt., s. 185.

${ }^{74}$ L. Sorell, Włosy gładko przyczesane, „Film” 1991, nr 19, s. 18

${ }^{75}$ M. Przylipiak, J. Szyłak, dz. cyt. s. 184.

${ }^{76}$ Tamże, s. 193.

${ }^{77}$ M. Cichosz, Transformacja demokratyczna przyczyny, przebieg, efekty procesu, w: Systemy polityczne Europy Środkowej i Wschodniej. Perspektywa porównawcza, red. A. Antoszewski, Wydawnictwo Uniwersytetu Wrocławskiego, Wrocław 2005, s. 36.

${ }^{78}$ M. Przylipiak, J. Szyłak, dz. cyt., s. 194.

${ }^{79}$ J. Staniszkis, Postkomunizm. Próba opisu, Słowo/obraz terytoria, Gdańsk 2005, s. 147.

${ }^{80}$ Tamże, s. 147-148. 